\title{
Innovative capabilities of users of agricultural R\&D services
}

\section{Rosmery Ramos-Sandoval ${ }^{1,2}$ (D) | José María García Álvarez-Coque ${ }^{1}$ (D) | Francisco Mas-Verdú ${ }^{1}$}

${ }^{1}$ Group of International Economics and Development, Universitat Politècnica de València, Camino de Vera, S/N, Valencia, Spain

${ }^{2}$ Centre for Interdisciplinary Science and Society Studies, Universidad de Ciencias y Humanidades, Los Olivos, Lima, Peru

\section{Correspondence}

Rosmery Ramos-Sandoval, Group of International Economics and Development, Universitat Politècnica de València, Camino de Vera, S/N, Valencia, Spain.

Email: rosrasan@posgrado.upv.es;

rramos@uch.edu.pe

\section{Funding information}

Ministry of Economy and Competitiveness, Grant/Award Number: AGL2015-65897-C3-3-R

JEL Classification: Q16; R00

\begin{abstract}
Innovation at farms is crucial to face technological, environmental and social challenges of the agricultural sector. Our hypothesis is that access from farmers to research $\&$ development services (RDS) is enhanced by certain entrepreneurial attributes (market orientation and learning orientation) as well as by their innovative attitude and human capital, as innovation capabilities. We explore the role of these factors in a sample of farmers in a region of Spain (Valencian Community), which is a context dominated by small and medium-sized farms. Through a logistic equation modelling approach, we tested the conditions that increase the likelihood to be users of RDS. Our findings suggest that both strategic and innovation capabilities, as well as a high level of formal education, are positively correlated with farmer's willingness to make use of RDS, while the largest group of farms shows a lower probability of adoption of RDS. Policies promoting knowledge intensive support services can pay attention to the fact that more innovative and educated farmers are also those who interact more with RDS, even in a context where small and medium-sized farms prevail.

\section{KEYWORDS}

farmers, human capital, innovation attitude, learning orientation, market orientation, R\&D Services, sub-territory 


\section{1 | INTRODUCTION}

Innovation in agriculture is now recognized as a key tool to address the great social challenges faced by rural economies. Progress towards a sustainable paradigm requires new ways of evaluating results and impacts of the Agricultural Knowledge and Innovation System (AKIS) (EU SCAR, 2012). The AKIS concept considers innovation in agriculture as a social process, were lineal models of innovation have been replaced by a cooperative approach, in which innovation is "co-produced" due to the interaction between farmers, researchers and intermediary actors within the system (EU SCAR, 2015). Therefore, fruitful links between agents become a desirable goal in the AKIS.

There are certain AKIS characteristics that demand an effective relationship between innovation intermediaries and small and medium-sized holdings. First, social returns from R\&D in agriculture are relatively high compared to other sectors (Alston, 2010). Second, the pursued benefits of innovation efforts in agriculture go beyond simple productivity increase; they also take into account broader contributions, including in the environmental and social areas (European Commission, 2017). Third, the public-sector role mainly concerns innovations that are complicated to protect (Alfranca, 2005). Finally, in comparison with other sectors, the speed of technological transfer from science to actual farming practice is quite low. Sutherland et al. (2017) argue that innovation potential has been lost in the agricultural sector, because of disconnection between scientific research and small-scale farmers. New approaches take too long to be put in place, given that in the EU small and medium-sized farms prevail, showing less ambition to engage in research and innovation than in other industries. Particularly because of the low applicability of basic research, recent EU agricultural and innovation policies have increasingly focused on the innovation potential of the agri-food sector. An example is the European Innovation Partnership (EIP) in agriculture, which works to foster a smart and sustainable multi-actor cooperation.

Understanding farmers' social and entrepreneurial attributes can help to improve the effectiveness of research \& development services (RDS), organizations identified as innovation intermediaries or cooperation tools addressed to agricultural holders and other rural stakeholders (Caputo, Cucchiella, Fratocchi, Pelagagge, \& Scacchia, 2002; Klerkx \& Leeuwis, 2008). The literature has extensively discussed the crucial role that innovation intermediaries play in the exploitation and dissemination of innovations, increasing both the speed and the innovative performance of organizations (De Silva, Howells, \& Meyer, 2018; Edler \& Yeow, 2016). However, there is less research on the type of contribution of different types of intermediaries (Kilelu, Klerkx, Leeuwis, \& Hall, 2011), especially in the agriculture sector. Seen as intermediary actors, RDS are supposed to facilitate intense interaction between actors in which human capital plays a critical role (Alvesson, 1995; Klerkx, Aarts, \& Leeuwis, 2010; Mas-Verdú, Wensley, Alba, \& García-Álvarez-Coque, 2011; Miles, 2005). Intermediary agents help to solve the challenges faced by agricultural entrepreneurs as well as to integrate their needs through a "service relationship" between providers and beneficiaries, through interactions leading to a co-production process (Faure et al., 2017). However, what is the perception of agricultural smallholders regarding RDS? Which cultural and structural attributes enhance the use of such services? We argue that the effectiveness of RDS is enhanced by entrepreneurial and cultural farmers' characteristics, such as their innovation attitude and their learning orientation.

In this paper a logit model is proposed to assess which aspects can influence the likelihood of farmers to use RDS, with focus on capacities connected with innovation, such as market orientation (MO), learning orientation (LO) and innovative attitude (IAT). We also consider specific characteristics related to human capital (education and age) as well as information on the size of holdings (gross margin), and territorial localization. We test the proposed framework in a sample of farmers at the region of Valencia based on a survey on innovation in agricultural operations carried out with farmers in the region, designed and collected ad hoc for this research.

\section{I CONCEPTUAL FRAMEWORK}

According to Touzard, Temple, Faure, and Triomphe (2015), despite the complexity of the AKIS, an interactionist view of innovation suggests to explore the key factors that influence the farmers' participation in the innovation networks. 
In this paper, we evaluate the role of RDS as intermediate agents in the AKIS system by assessing the characteristics of small and medium-sized agricultural holders that make use of RDS.

RDS fulfil different functions to promote knowledge dissemination: advisory, consultancy and technical support; demand articulation; networking, facilitation and brokerage; capacity building; institutional support and scaling-up mechanisms (Faure et al., 2017; Mathe et al., 2016). In order to investigate farmer's values and attitudes towards support services, we first need to define the relevant constructs and attributes that characterize farmers' behaviour. We will proceed then to test their influence on the farmers' likelihood to make use of RDS.

RDS should be locally adequate to farmers, according to their own contexts and individual priorities, hence the relevance to focus on farmers' views about the RDS adoption. Related to this, research about innovation in agriculture cannot avoid the study of subjective cultural constructs that involve perceptions and beliefs (Borges, Oude Lansink, Marques Ribeiro, \& Lutke, 2014). We propose to focus on farmers' market orientation, learning orientation and innovative attitudes as core characteristics that can influence farmers' use of RDS. We also consider certain individual characteristics of agricultural holdings such as human capital (age \& education level), geographic localization and farm size, considered here as control variables. We focus then on a regional context approach through a case study in the Spanish region of Valencian Community.

\section{1 | Market orientation (MO)}

As a component of the farmer's innovation behaviour, MO provides information about the entrepreneurial orientation of farmers and the relationship between them and other market actors. MO is recognized as a cultural variable which is also identified as a behavioural characteristic in contexts where internal innovation determines the process in which individuals develop and implement firm's strategies based on information given by market trends, competitors and customers (Kohli \& Jaworski, 1990; Narver \& Slater, 1990). Micheels and Gow (2014) describe MO as a heterogeneous intangible firm's cultural resource that integrates articulated new information that includes needs of potential or actual markets and consumers. Empirically, previous literature concludes that the MO significantly enhances business performance in a context also influenced by the learning orientation of individuals in firms (Baker \& Sinkula, 2002; Lin, Peng, \& Kao, 2008; Slater \& Narver, 1995).

\section{2 | Learning orientation (LO)}

Hurley and Hult (1998) consider learning orientation as a strategic tool required to build a culture where firms become organizations receptive to innovation. In this research, LO focus on knowledge-sharing and its assimilation to become essential capabilities aiming to assimilate new ideas about market dynamic and innovation. In line with MO, Narver and Slater (1990) highlight the organizational culture in firms, which allows managers to learn fast about market developments. Consequently, LO is considered an important capability that joins market orientation as a baseline to innovativeness (Baker \& Sinkula, 2002; Day, 1994; Sinkula, Baker, \& Noordewier, 1997). Small and medium-sized holders need to integrate knowledge and learning capacities as resources to improve organizational performance (Ibrahim \& Heng, 2015). We propose learning orientation as an antecedent to innovation behaviour, which also, in synergy with MO, provides a baseline for technical and organizational change (Ramos-Sandoval, García-Álvarez-Coque, \& Mas-Verdú, 2016).

\section{3 | Innovative attitude (IAT)}

Gellynck and Kühne (2008) describes innovation capabilities as a set of dynamic processes based on searching and exploring, which eventually results in knowledge generation and absorption to be converted into new products, new techniques or new markets. Lee and Tsai (2005) state that an interactive cooperation among firms has an important role when comes to encouraging the internalization of the market and learning orientation. At a farm level, innovation capabilities could facilitate firms to be more aware of opportunities within markets trends and new processes, 
which allows them to strengthen their position in the value chain (Micheels \& Gow, 2014). A shift from a simple "transfer of technology" approach to an "innovation system" approach is considered desirable in the AKIS (Wielinga, Koutsouris, Knierim, \& Guichaoua, 2017). Here the study on how innovation attitudes affect small holders' collaboration with RDS becomes increasingly relevant.

\subsection{Human capital characteristics}

There are several individual characteristics that can be proposed as human capital factors that may influence the likelihood of farm's managers to adopt RDS. In this research, we propose two main individual attributes: agricultural holders' age and education levels. Farmer's age was formulated in our model as a dummy variable that captures two time horizons of individuals: young farmer ( $\leq 40$ years) and senior farmers (>40 years). Diederen, van Meijl, Wolters, and Bijak (2003) suggest that senior farmers are usually less interested in assimilating external information, which could hamper their access to information about market trends or competitor's information. Experienced farm managers may show less willingness to take the risk of implementing innovations in their farms (Micheels \& Gow, 2014). Younger farmers would show a better connection to new knowledge and would display a riskier attitude. Läpple, Renwick, and Thorne (2015) underline the relevance of farmers' risk attitude in the process of innovation adoption.

Furthermore, we evaluated the education level as a dummy variable that distinguishes between farmers with a technical or university degree from those who lack any professional training. O'Donoghue and Heanue (2018) stress that the quality of education matters and they suggest that the influence of education depends on whether it is formal or informal, it has either long or short-term length or it is accredited or not. Finally, they conclude that a close connection between education level and the advisory and extension services may improve the effectiveness of the knowledge services as well as the mutual understanding between scientists and farm managers, which is not always fruitful (McCown, 2002).

\section{5 | Farm size}

Whereas the relationship between firm size and innovation has been commonly investigated in the industrial and technology sector (Acs \& Audretsch, 2005; Pavitt, Robson, \& Townsend, 1987), we evaluate the influence of the size of agricultural holdings on their managers' propensity to make use of RDS. Our survey allowed to group farm sizes in five categories of farm gross income: (i) below 5,000 euro; (ii) 5,000-10,000 euro; (iii) 10,000-20,000 euro; (iv) 20,000-50,000 euro; and (v) above 50,000 euro. This classification allows to capture the micro-farms which are relevant in the Mediterranean context. Langemeier and Jones (2000) suggest a relation between farm size and their financial capability to invest, which may pose a limitation because priorities that especially small and medium farms face. Related to these, large farms would show an enhanced capacity to invest in new technologies and equipment, which is normally constrained for small farms (Laforet, 2008; Laforet \& Tann, 2006). Pascucci and De-Magistris (2012) associate farm size with organizational complexity as a factor for farmers' technology choices. García-ÁlvarezCoque, Mas-Verdú, and Sanchez-García (2015) highlight the problems that small and medium enterprises in the agrifood sector face to carry out R\&D projects in partnership with universities and research centres. However, large farmers may have better connections with agribusiness and lower incentives to collaborate with public RDS.

\section{6 | Sub-territory}

Previous research (Fearne, García-Álvarez-Coque, López-García-Usach, \& Sanchez-García, 2013) has underlined the role of territorial factors in explaining the participation of agri-food firms in R\&D partnerships. García Alvarez-Coque et al. (2015) confirm the existence of certain conditions that allow small firms to take part in R\&D projects and networking, such as the proximity to the knowledge centres and the collaboration within food clusters. We divided our sample into three provinces. Valencia and Alicante, with larger urbanized areas, and Castellón, with the more 
predominant rural population. Valencia benefits from holding the regions' capital city, with a significant concentration of universities and agricultural research centres. Therefore, in order to determinate the territorial influence, a categorical variable was included to evaluate in the model the effect of farmers' location in the three region's provinces.

\section{3 | DATA AND METHODOLOGY}

Data collection and analysis were according with a local approach that allows a statistical evaluation of farmers' perception regarding the regional innovation system. A survey was designed aiming to make an introspective evaluation of farmers' innovative attitude in the region of Valencia. Data were collected from May to December of 2012 obtaining a 40.80\% response rate, with 247 surveys completed, each one randomly selected, with a sampling error of $6.3 \%$ at an acceptable level of confidence, given a total census of $N \geq 100000$ holdings, based on available datasets: "Agricultural Census" (INE, 2009) and the "Survey on Agricultural Structure" (INE, 2007).

Pérez-Ledo (2013) indicates the particular agro-climatic conditions in Valencia as one factor for productive specialization: $80 \%$ of its agricultural final production corresponds to Mediterranean crops (fruits, vegetables, rice, vineyards, and olive trees, among others). Valencia is, therefore, a territory with specific agricultural conditions to explore, with most of its production oriented to export outlets. Table 1 presents the basic characteristics of the surveyed farms.

A construct for the farmers' use of RDS was built as an indicator of the propensity of surveyed farmers to resort to RDS (Segarra-Blasco \& Arauzo-Carod, 2008). Questions related to such use were organized in three Likert scales (1 to 7):

RDS1 I usually take advice from research centres and universities,

RDS2 I take part in projects of research and innovation undertaken by public or private organizations,

RDS3 I consult agricultural county offices to apply the best techniques.

A binomial variable was designed and built by applying a cluster analysis on the RDS construct based on the defined scales. The variables obtained from the non-hierarchical cluster process were segmented through SPSS@ into

TABLE 1 Description of the sample

\begin{tabular}{|c|c|c|c|}
\hline Variables & Frequency & Mean & S.D \\
\hline Age & 247 & 48.16 & 11.396 \\
\hline Education Level & & 1.53 & 0.500 \\
\hline No professional training & 115 & & \\
\hline Technical / University degree & 132 & & \\
\hline Sub-Territory & & 2.64 & 0.659 \\
\hline Alicante & 25 & & \\
\hline Castellón & 39 & & \\
\hline Valencia & 183 & & \\
\hline Farm Size & & 3.07 & 1.145 \\
\hline Below 5,000 euro & 16 & & \\
\hline $5,000-10,000$ euro & 69 & & \\
\hline $10,000-20,000$ euro & 79 & & \\
\hline $20,000-50,000$ euro & 47 & & \\
\hline Above 50,000 euro & 36 & & \\
\hline
\end{tabular}

Notes: $n=247$ farmer respondents. Education level, Sub-Territory, and Farm Size are reported in absolute frequencies.

Source: Prepared by authors based on the project survey. 
two categories ( $Y=1$, RDS user; $Y=0$, No RDS user). Through this technique, a total of 92 farmers were identified as RDS users, whereas as 155 farmers were identified as no RDS users (Table 2). At the same time, three constructs were built to describe $M O_{i}, L O_{i}$, IAT , based on the scales in Table 2, which also resulted from survey responses.

The functional equation of the logit model is displayed in Equation (1):

$$
\widehat{p}=\operatorname{Prob}(Y=1)=E(Y=1 X)=\frac{\exp ^{\times \beta}}{1+\exp ^{\times \beta}}
$$

where $\mathrm{Y}$ is the dependent variable RDS. $\mathrm{Y}=1$ means $\mathrm{RDS}=1$, that is, the farmer being a RDS user. $\mathrm{X}$ are the independent variables: $M O_{i}$; $L O_{i}$; IAT ; education level $\left(E d_{L}\right)$ and farmers' age $(A g e)$ as individual respondent conditions; the gross margin $\left(F_{s}\right)$ to identify the firm size; and Sub-Territory $\left(T_{\text {sub }}\right)$ that indicates the geographical localization. The log transformation of equation (1) yields the following linear regression (2):

$$
\ln \left(\frac{R D S_{u s e r}}{1-R D S_{u s e r}}\right)=\beta_{0}+\beta_{1} M O_{i}+\beta_{2} L O_{i}+\beta_{3} I A T_{i}+\beta_{4} E d_{L}+\beta_{5} A g e+\beta_{6} F_{s}+\beta_{7} F_{s}^{2}+\beta_{8} T_{\text {sub }}+\varepsilon
$$

\section{4 | MAIN FINDINGS AND DISCUSSION}

Model fit evaluation from a preliminary logistic regression that just considers the dependent variable indicates a certainty ratio of $62.8 \%$, assuming a scenario that respondents are non-RDS users. When the independent variables were added to the regression evaluation, the model displayed adequate goodness of fit indices for the logistic regression: -2 log likelihood $=269.162 ; R^{2}$ Nagelkerke $=0.281$ to explaining the variance of the dependent variable at $28.1 \%$. The Hosmer and Lemeshow (1980) measures explain the model capacity of prediction: Chi square $=6.519 ; d f=8$;

\begin{tabular}{|c|c|c|c|c|c|c|c|}
\hline \multirow[b]{2}{*}{ Construct } & \multirow[b]{2}{*}{ Variables } & \multicolumn{3}{|c|}{ RDS User / $n=92$} & \multicolumn{3}{|c|}{$\begin{array}{l}\text { No RDS User / } \\
n=155\end{array}$} \\
\hline & & Mean & $\begin{array}{l}\text { Std. } \\
\text { Dev }\end{array}$ & $\begin{array}{l}\text { Std. } \\
\text { Error }\end{array}$ & Mean & $\begin{array}{l}\text { Std. } \\
\text { Dev }\end{array}$ & $\begin{array}{l}\text { Std. } \\
\text { Error }\end{array}$ \\
\hline \multirow[t]{3}{*}{$\begin{array}{l}\text { MO (Narver \& } \\
\text { Slater, 1990) }\end{array}$} & $\begin{array}{l}\text { I follow the quality guidelines I } \\
\text { receive from clients. }\end{array}$ & 6.24 & 1.093 & 0.114 & 5.45 & 1.555 & 0.125 \\
\hline & $\begin{array}{l}\text { My interest in quality gives me } \\
\text { advantages over other holdings. }\end{array}$ & 5.74 & 1.511 & 0.158 & 4.90 & 1.880 & 0.151 \\
\hline & $\begin{array}{l}\text { - Customer satisfaction is the main } \\
\text { goal of my holding. }\end{array}$ & 6.18 & 0.994 & 0.104 & 5.44 & 1.834 & 0.147 \\
\hline \multirow{3}{*}{$\begin{array}{l}\text { LO (Calantone, Cavusgil, } \\
\text { \& Zhao, 2002; Hult, 1998; } \\
\text { Johnson, Meyer, Berkowitz, } \\
\text { Ethington, \& Miller, 1997) }\end{array}$} & $\begin{array}{l}\text { I like reading magazines or view } \\
\text { media about new crops or methods } \\
\text { that I could introduce. }\end{array}$ & 6.14 & 1.210 & 0.126 & 5.23 & 1.720 & 0.138 \\
\hline & $\begin{array}{l}\text { I enjoy attending fairs, courses, or } \\
\text { seminars to learn new ideas. }\end{array}$ & 6.14 & 1.044 & 0.109 & 5.35 & 1.712 & 0.137 \\
\hline & $\begin{array}{l}\text { When a new technique/product does } \\
\text { not yield results, I analyze the causes } \\
\text { of the failure. }\end{array}$ & 6.09 & 1.023 & 0.10700 & 5.39 & 1.630 & 0.131 \\
\hline \multirow{6}{*}{$\begin{array}{l}\text { IAT (Harrison, Mykytyn, \& } \\
\text { Riemenschneider, 1997; } \\
\text { Sophonthummapharn, 2009; } \\
\text { Venkatesh \& Davis, 2000) }\end{array}$} & $\begin{array}{l}\text { Adopting innovation is a useful } \\
\text { decision. }\end{array}$ & 6.12 & 1.098 & 0.1014 & 5.28 & 1.650 & 0.133 \\
\hline & I value people that innovate. & 6.28 & 1.083 & 0.113 & 5.78 & 1.378 & 0.111 \\
\hline & $\begin{array}{l}\text { The people who are important for } \\
\text { me believe that I should innovate. }\end{array}$ & 5.51 & 1.456 & 0.152 & 4.44 & 1.809 & 0.145 \\
\hline & I am motivated to innovate. & 5.39 & 1.791 & 0.187 & 4.14 & 2.167 & 0.174 \\
\hline & $\begin{array}{l}\text { Innovations improve the results } \\
\text { of my farm. }\end{array}$ & 5.68 & 1.526 & 0.159 & 4.74 & 1.948 & 0.156 \\
\hline & - Innovation pays off. & 5.55 & 1.699 & 0.177 & 4.82 & 1.925 & 0.155 \\
\hline
\end{tabular}

TABLE 2 Description of cluster segmentation from construct R\&D Services

Source: Prepared by authors based on the project survey. 
$p$ value $=0.589$ and indicate a high level of non-significance, which is an index of higher level of reliability for the logit modelling. The ratio of certainty also increases around at $8.9 \%$, when the independent variables are added to the model (70.9\%). Outcomes obtained from linear logistic formulation are the set of regression coefficients $(\beta)$, including the intercept $\left(\beta_{0}\right)$ and the coefficients labelled $\left(\beta_{1} ; \beta_{2} ; \beta_{3} ; \beta_{4} ; \beta_{5} ; \beta_{6} ; \beta_{7} ; \beta_{8}\right)$ that are significant $(p<0.05)$ in four variables from the model proposed (Table 3). These measures identify conditions for farmers to adopt the RDS except for $\mathrm{MO}_{i}(p=0.060)$, any of sub-territory categories $\left(T_{\text {sub }} ; T_{\text {sub } 2} ; T_{\text {sub } 3}\right)$, age $(p-$ value $=0.773)$; and three of the five categories of farm size: $F_{s 1}(p-$ value $=0.096) ; F_{s 2}(p-$ value $=0.114) ;$ and $F_{s 3}(p-$ value $=0.061)$.

The results for variables with significant $p$-values and odds ratio > 1 (Table 3) confirm the relevance of some variables, $L O_{i}, I A T_{i}, E d_{L}, F_{s}$, as enhancers of the likelihood of farmers to be RDS users.

Table 2 shows, MO, LO, and IAT scale Likert means in RDS users group that were classified above 6, which allowed to identify a high level score of these characteristics in farmers who are RDS users. In this regard, we identified that farmers with relatively high levels of innovation attitude increased their likelihood to be a RDS user, up to $85 \%$. High levels of learning orientation can also increase by $64 \%$ the farmers' probability to adopt innovation support services.

About the influence of socio-economic or contextual characteristics, levels of high formal education such as technical or college studies were also a factor that nearly duplicates (odds ratio $=2.241$ ) the farmers' probability to use RDS. In his research on small-holders, Läpple et al. (2015) prove the relevance of higher education in farmers' condition to make them more able to absorb new information or adapting knowledge in a more efficient way. The role of education in agriculture is crucial within the innovation process because education drives farmers to widen their sources of information (O'Donoghue \& Heanue, 2018) and to expand their networks (Faure et al., 2017).

The fact that age is not independently significant might be due to the role of education, which can be more determining of a higher use of RDS than age by itself. On the other hand, within the largest farm size category, the probability of farmers to be users of RDS is reduced by $10 \%$. This finding would need further investigation but suggests that larger farms may resort to alternative knowledge sources, perhaps in connection with agribusiness. It can be also indicative of a crucial role from RDS in supporting small and medium-sized holdings.

In this regard, agricultural innovation is a process which cannot be simply understood as a top-down process related to technology adoption (Dedieu et al., 2009), but as an interactive process in which innovation policies need to consider characteristics of agricultural holders that improve the effectiveness of the AKIS.

TABLE 3 Estimates of logistic regression

\begin{tabular}{|c|c|c|c|c|c|c|c|c|}
\hline \multirow[b]{2}{*}{ Variable } & \multirow[b]{2}{*}{$\beta$} & \multirow[b]{2}{*}{ S.E. } & \multirow[b]{2}{*}{ Wald } & \multirow[b]{2}{*}{ df } & \multirow[b]{2}{*}{ Sig. } & \multirow{2}{*}{$\begin{array}{l}e^{(\beta)}=\text { Odds } \\
\text { ratio }\left(^{*}\right)\end{array}$} & \multicolumn{2}{|c|}{ 95\% C.I. for $\operatorname{EXP}(\beta)$} \\
\hline & & & & & & & Lower & Upper \\
\hline$M O_{i}$ & 0.451 & 0.240 & 3.524 & 1 & 0.060 & 1.570 & 0.980 & 2.513 \\
\hline $\mathrm{LO}_{i}$ & 0.493 & 0.239 & 4.263 & 1 & 0.039 & 1.637 & 1.025 & 2.614 \\
\hline$I A T_{i}$ & 0.617 & 0.238 & 6.704 & 1 & 0.010 & 1.852 & 1.162 & 2.954 \\
\hline Age & 0.004 & 0.014 & 0.083 & 1 & 0.773 & 1.004 & 0.977 & 1.032 \\
\hline$E d_{L}$ & 0.807 & 0.317 & 6.461 & 1 & 0.011 & 2.241 & 1.203 & 4.175 \\
\hline $\mathrm{F}_{\mathrm{s}}(<5000 €=0)$ & & & 9.936 & 4 & 0.042 & & & \\
\hline $\mathrm{F}_{\mathrm{s} 1}(5000-10000 €)$ & -1.100 & 0.660 & 2.778 & 1 & 0.096 & 0.333 & 0.091 & 1.214 \\
\hline$F_{\mathrm{s} 2}(10000-20000 €)$ & -1.040 & 0.657 & 2.505 & 1 & 0.114 & 0.354 & 0.098 & 1.281 \\
\hline $\mathrm{F}_{\mathrm{s} 3}(20000-50000 €)$ & -1.292 & 0.690 & 3.506 & 1 & 0.061 & 0.275 & 0.071 & 1.062 \\
\hline $\mathrm{F}_{\mathrm{s} 4}(>50000 €)$ & -2.339 & 0.774 & 9.134 & 1 & 0.003 & 0.096 & 0.021 & 0.439 \\
\hline$T_{\text {sub }}($ Alicante $=0$ ) & & & 2.966 & 2 & 0.227 & & & \\
\hline$T_{\text {sub2 }}$ (Castellon) & -0.256 & 0.660 & 0.150 & 1 & 0.698 & 0.774 & 0.212 & 2.822 \\
\hline$T_{\text {sub3 }}$ (Valencia) & 0.497 & 0.499 & 0.992 & 1 & 0.319 & 1.644 & 0.618 & 4.371 \\
\hline Constant & -3.611 & 1.393 & 6.724 & 1 & 0.010 & 0.027 & & \\
\hline
\end{tabular}

Note: $\left(^{*}\right)$ Odds ratio confidence interval at $95 \%$.

Source: Prepared by authors based on the project survey. 


\section{5 | CONCLUDING REMARKS}

In previous sections, we provided a framework that allowed us to: (i) measuring some innovative capabilities of agricultural holders; and (ii) evaluating their willingness to adopt RDS. We found that behavioural and cultural resources explain why some holders make use of RDS more than others. Holders' learning orientation and innovative attitude were identified as enabling internal conditions that enhance an entrepreneurial orientation that may increase the likelihood of a holder to be RDS adopter, even in territorial contexts where small-scaled agricultural holders are predominant. In this regard, it is outstanding that the most motivated group of farmers are the more active RDS users, which also are those more prone to capture and share knowledge. Market orientation considered by itself is not significant, at least if it is not accompanied by an innovation attitude and a learning orientation.

These findings would need to be taken into account in the formulation of territorial innovation policies such as future developments of the European Innovation Partnership for agriculture productivity and sustainability. Our results reveal that innovation policies need to consider farmers' cultural and social attributes in order to enhance the effectiveness of RDS, which interact with more innovative and educated farmers. The new interactive and bottom-up innovation approach is not easy to implement because in certain places there are issues regarding collective action and weaknesses in initiatives where farmers lack training and professionalism.

The education level of farmers, in our research context, plays a significant role that increases their likelihood to become RDS users, which is consistent with previous research suggesting that educated farmers are more willing to participate in networking activities with other agents of the innovation system. Also, our findings reveal the importance of an educational system that promotes innovation and a learning orientation and further fosters linkages between farmers and RDS.

Age and some categories of farm size do not seem to be relevant to discriminate between RDS users and nonusers. The fact that large holdings in our research context have a negative effect on the probabilities that farmers become RDS users, should be better explored, perhaps by investigating the role of agribusiness in the AKIS or by better specifying the typology of innovation support services also in research contexts where small holdings are not predominant.

The nature of future generations of farmers as real entrepreneurs will help to enhance their effective use of innovation support services from the local AKIS. Future farm advisory services should be designed to strengthen the EIP's Agricultural Productivity and Sustainability Programme in order to improve innovation support systems for farmers and to facilitate the adoption of new and relevant technologies for farms.

\section{ACKNOWLEDGEMENTS}

We acknowledge support of the Project AGL2015-65897-C3-3-R funded by the Ministry of Economy and Competitiveness, for this research.

\section{ORCID}

Rosmery Ramos-Sandoval (D) http://orcid.org/0000-0002-7447-7464

José María García Álvarez-Coque (D) http://orcid.org/0000-0002-4334-7843

Francisco Mas-Verdú (D) http://orcid.org/0000-0002-0902-9462

\section{REFERENCES}

Acs, Z. J., \& Audretsch, D. B. (2005). Entrepreneurship, innovation and technological change. Foundations and Trends in Entrepreneurship, 1(4), 149-195.

Alfranca, O. (2005). Private R\&D and spillovers in European agriculture. International Advances in Economic Research, 11(2), 201-213. https://doi.org/10.1007/s11294-005-3016-7

Alston, J. (2010). The benefits from agricultural research and development, innovation and productivity growth. OECD, Food, Agriculture and Fisheries Papers No 31. Retrieved from https://doi.org/10.1787/5km91nfsnkwg-en 
Alvesson, M. (1995). Management of knowledge-intensive companies. Berlin: Walter de Gruyter.

Baker, W. E., \& Sinkula, J. M. (2002). Market orientation, learning orientation and product innovation: delving into the organization's black box. Journal of Market-Focused Management, 5(1), 5-23.

Borges, J. A. R., Oude Lansink, A. G. J. M., Marques Ribeiro, C., \& Lutke, V. (2014). Understanding farmers' intention to adopt improved natural grassland using the theory of planned behavior. Livestock Science, 169, 163-174. https://doi.org/ 10.1016/j.livsci.2014.09.014

Calantone, R. J., Cavusgil, S. T., \& Zhao, Y. (2002). Learning orientation, firm innovation capability, and firm performance. Industrial Marketing Management, 31, 515-524.

Caputo, A. C., Cucchiella, F., Fratocchi, L., Pelagagge, P. M., \& Scacchia, F. (2002). A methodological framework for innovation transfer to SMEs. Industrial Management \& Data Systems, 102(5), 271-283.

Day, G. (1994). The capabilities of market-driven organizations. Journal of Marketing, 58(4), 37-52.

De Silva, M., Howells, J., \& Meyer, M. (2018). Innovation intermediaries and collaboration: Knowledge-based practices and internal value creation. Research Policy, 47(1), 70-87.

Dedieu, B., Darnhofer, I., Bellon, S., De Greef, K., Casabianca, F., Madureira, L., ... Zasser-Bedoya, S. (2009). Special issue: Innovations in farming systems approaches. Introduction. Outlook on Agriculture, 38(2), 108-110.

Diederen, P., van Meijl, H., Wolters, A., \& Bijak, K. (2003). Innovation adoption in agriculture: Innovators, early adopters and laggards. Cahiers d'Économie et Sociologie Rurales, 67, 30-50.

Edler, J., \& Yeow, J. (2016). Connecting demand and supply: The role of intermediation in public procurement of innovation. Research Policy, 45(2), 414-426.

EU SCAR (2012). Agricultural knowledge and innovation systems in transition - A reflection paper, Brussels. Retrieved from https://doi.org/10.2777/34991

EU SCAR (2015). Agricultural knowledge and innovation systems towards the future - A foresight paper. Retrieved from https://doi.org/10.2777/324117

European Commission (2017). The Future of Food and Farming. Communication from the Commission to the European Parliament, the Council, the European Economic and Social Committee and the Committee of the Regions, Brussels, 29.11.2017 $\operatorname{COM(2017)~} 713$ final. Retrieved from https://ec.europa.eu/agriculture/sites/agriculture/files/future-ofcap/future_of_food_and_farming_communication_en.pdf

Faure, G., Knierim, A., Koutsouris, A., Ndah, H. T., Audouin, S., Zarokosta, E., ... Heanue, K. (2017). How to strengthen innovation support services in European rural areas: Lessons learnt from AgriSpin Authors. In European Seminar on Extension and Education (ESEE 2017), 23, Chania, 4 July-7 July 2017 (pp. 1-17). Retrieved from http://agritrop.cirad.fr/585168/

Fearne, A., García-Álvarez-Coque, J. M., López-García-Usach, T., \& Sanchez-García, M. (2013). Innovative firms and the urban/rural divide: the case of agro-food system. Management Decision, 51(6), 1293-1310.

García-Álvarez-Coque, J. M., Mas-Verdú, F., \& Sanchez-García, M. (2015). Determinants of Agri-food Firms' Participation in Public Funded Research and Development. Agribusiness, 31(3), 314-329.

Gellynck, X., \& Kühne, B. (2008). Innovation and collaboration in traditional food chain networks. Journal on Chain and Network Science, 8(2), 121-129. https://doi.org/10.3920/JCNS2008.x094

Harrison, D., Mykytyn, P., \& Riemenschneider, C. (1997). Executive decisions about adoption of information technology in small business: Theory and empirical tests. Information Systems Research, 8(2), 171-195. https://doi.org/10.1287/ isre.8.2.171

Hosmer, D., \& Lemeshow, S. (1980). A goodness-of-fit test for the multiple logistic regression model. Communications in Statistics, A10, 1043-1069.

Hult, G. T. (1998). Managing the international strategic sourcing process as a market-driven organizational learning system. Decision Sciences, 29(1), 193-216.

Hurley, R. G., \& Hult, G. T. (1998). Innovation, market orientation, and organizational learning: An ntegrated and empirical examination. Journal of Marketing, 62(3), 42-54.

Ibrahim, S., \& Heng, L. H. (2015). The roles of learning in stimulating knowledge sharing at SMEs. Procedia - Social and Behavioral Sciences, 172, 230-237. https://doi.org/10.1016/j.sbspro.2015.01.359

INE (2007). Encuesta de estructuras agrícolas 2007. Instituto Nacional de Estadística, España. Retrieved from http://www.ine.es

INE (2009). Censo Agrario 2009. Instituto Nacional de Estadística, España. Retrieved from http://www.ine.es

Johnson, J. D., Meyer, M. E., Berkowitz, J. M., Ethington, C. T., \& Miller, V. D. (1997). Testing two contrasting structural models of innovativeness in a contractual network. Human Communication Research, 24(2), 320-348. 
Kilelu, C. W., Klerkx, L., Leeuwis, C., \& Hall, A. (2011). Beyond knowledge brokering: An exploratory study on innovation intermediaries in an evolving smallholder agricultural system in Kenya. Knowledge Management for Development Journal, 7(1), 84-108.

Klerkx, L., Aarts, N., \& Leeuwis, C. (2010). Adaptive management in agricultural innovation systems: The interactions between innovation networks and their environment. Agricultural Systems, 103(6), 390-400.

Klerkx, L., \& Leeuwis, C. (2008). Establishment and embedding of innovation brokers at different innovation system levels: Insights from the Dutch agricultural sector. Technological Forecasting and Social Change, 76, 849-860.

Kohli, A. K., \& Jaworski, B. J. (1990). Marketing orientation: The construct, research proposition, and managerial implications. Journal of Marketing, 54, 1-18.

Laforet, S. (2008). Size, strategic, and market orientation affects on innovation. Journal of Business Research, 61(7), 753-764. https://doi.org/10.1016/j.jbusres.2007.08.002

Laforet, S., \& Tann, J. (2006). Innovative characteristics of small manufacturing firms. Journal of Small Business and Enterprise Development, 13(3), 363-380.

Langemeier, M. R., \& Jones, R. D. (2000). Measuring the impact of farm size and specialization on financial performance. Journal of the American Society of Farm Managers and Rural Appraisers, 63(1), 90-96.

Läpple, D., Renwick, A., \& Thorne, F. (2015). Measuring and understanding the drivers of agricultural innovation: Evidence from Ireland. Food Policy, 51, 1-8. https://doi.org/10.1016/j.foodpol.2014.11.003

Lee, T. S., \& Tsai, H. J. (2005). The effects of business orientation mode on market orientation, learning orientation and innovativeness. Industrial Management \& Data Systems, 105(3), 325-348.

Lin, C., Peng, C., \& Kao, D. (2008). The innovativeness effect of market orientation and learning orientation on business performance. International Journal of Manpower, 29(8), 752-772.

Mas-Verdú, F., Wensley, A., Alba, M., \& García-Álvarez-Coque, J. M. (2011). How much does KIBS contribute to the generation and diffusion of innovation? Service Business, 5(3), 195-212.

Mathe, S., Faure, G., Knierim, A., Koutsouris, A., Ndah, H. T., Temple, L., ... Zarokosta, E. (2016). Typology of innovation support services, WP1 AgriSpin, deliverable 1.4. France: CIRAD, Montpellier.

McCown, R. (2002). Changing systems for supporting farmers' Decisions: problems, paradigms, and prospects. Agricultural Systems, 74(1), 179-220. https://doi.org/10.1016/S0308-521X(02)00026-4

Micheels, E. T., \& Gow, H. R. (2014). The effect of market orientation on learning, innovativeness, and performance in primary agriculture. Canadian Journal of Agricultural Economics, 63(2), 209-233. https://doi.org/10.1111/cjag.12047

Miles, I. (2005). Knowledge intensive business services: Prospects and policies. Foresight, 7(6), 39-63. https://doi.org/ $10.1108 / 14636680510630939$

Narver, J. C., \& Slater, S. F. (1990). The effect of a market orientation on business profitability. Journal of Marketing, 54(4), 20-35.

O'Donoghue, C., \& Heanue, K. (2018). The impact of formal agricultural education on farm level innovation and management practices. The Journal of Technology Transfer, 43(4), 844-863.

Pascucci, S., \& De-Magistris, T. (2012). Factors affecting farmers' likelihood to use advisory and extension services. New Medit, 11(3), 2-11.

Pavitt, K., Robson, M., \& Townsend, J. (1987). The size distribution of innovating firms in the UK: 1945-1984. Journal of Industrial Economy, 45, 297-306.

Pérez-Ledo, P. (2013). Perfil innovador de l'agricultura Valenciana. Anàlisi dels factors que sustenten els procesos d'innovació en l'agricultura valenciana del segle XXI des d'un enfocament socioeconòmic. Tesis doctoral. Editorial Universitat Politècnica de València. Retrieved from https://doi.org/10.4995/Thesis/10251/32828

Ramos-Sandoval, R., García-Álvarez-Coque, J. M., \& Mas-Verdú, F. (2016). Innovation behaviour and the use of research and extension services in small-scale agricultural holdings. Spanish Journal of Agricultural Research, 14(4), 1-14. https://doi. org/10.5424/sjar/2016144-8548

Segarra-Blasco, A., \& Arauzo-Carod, J. (2008). Sources of innovation and industry-university interaction: Evidence from Spanish firms. Research Policy, 37, 1283-1295.

Sinkula, J. M., Baker, W. E., \& Noordewier, T. (1997). A framework for market based organizational learning: Linking values, knowledge, and behavior. Journal of the Academy of Marketing Science, 25(4), 305-318.

Slater, S. F., \& Narver, J. C. (1995). Market orientation and the learning organization. Journal of Marketing, 59(3), 63-74.

Sophonthummapharn, K. (2009). The adoption of techno-relationship innovations. A framework for electronic customer relationship management. Marketing Intelligence \& Planning, 27, 380-412. 
Sutherland, L.-A., Madureira, L., Dirimanova, V., Bogusz, M., Kania, J., Vinohradnik, K., ... Knierim, A. (2017). New knowledge networks of small-scale farmers in Europe's periphery. Land Use Policy, 63, 428-439. https://doi.org/10.1016/j. landusepol.2017.01.028

Touzard, J.-M., Temple, L., Faure, G., \& Triomphe, B. (2015). Innovation systems and knowledge communities in the agriculture and agrifood sector: A literature review. Journal of Innovation Economics, 17(2), 117. https://doi.org/10.3917/ jie.017.0117

Venkatesh, V., \& Davis, F. D. (2000). A theoretical extension of the technology acceptance model: Four longitudinal field studies. Management Science, 45(2), 186-204.

Wielinga, E., Koutsouris, A., Knierim, A., \& Guichaoua, A. (2017). Generating space for innovations in agriculture: The AgriSpin project. Studies in Agricultural Economics, 119(1), 26-33. https://doi.org/10.7896/j.1043

How to cite this article: Ramos-Sandoval R, García Álvarez-Coque JM, Mas-Verdú F. Innovative capabilities of users of agricultural R\&D services. Reg Sci Policy Pract. 2018;1-11. https://doi.org/10.1111/rsp3.12152 